\title{
Space-based passive microwave soil moisture retrievals and the correction for a dynamic open water fraction
}

\author{
B. T. Gouweleeuw ${ }^{1}$, A. I. J. M. van Dijk ${ }^{1}$, J. P. Guerschman ${ }^{1}$, P. Dyce ${ }^{1}$, and M. Owe ${ }^{2}$ \\ ${ }^{1}$ CSIRO Land and Water, Canberra, ACT, Australia \\ ${ }^{2}$ NASA/Goddard Space Flight Center, Greenbelt, MD, USA \\ Correspondence to: B. T. Gouweleeuw (ben.gouweleeuw@csiro.au)
}

Received: 31 December 2011 - Published in Hydrol. Earth Syst. Sci. Discuss.: 18 January 2012

Revised: 12 May 2012 - Accepted: 21 May 2012 - Published: 8 June 2012

\begin{abstract}
The large observation footprint of low-frequency satellite microwave emissions complicates the interpretation of near-surface soil moisture retrievals. While the effect of sub-footprint lateral heterogeneity is relatively limited under unsaturated conditions, open water bodies (if not accounted for) cause a strong positive bias in the satellite-derived soil moisture retrieval. This bias is generally assumed static and associated with large, continental lakes and coastal areas. Temporal changes in the extent of smaller water bodies as small as a few percent of the sensor footprint size, however, can cause significant and dynamic biases. We analysed the influence of such small open water bodies on near-surface soil moisture products derived from actual (non-synthetic) data from the Advanced Microwave Scanning Radiometer for the Earth Observing System (AMSR-E) for three areas in Oklahoma, USA. Differences between on-ground observations, model estimates and AMSR-E retrievals were related to dynamic estimates of open water fraction, one retrieved from a global daily record based on higher frequency AMSRE data, a second derived from the Moderate Resolution Imaging Spectroradiometer (MODIS) and a third through inversion of the radiative transfer model, used to retrieve soil moisture. The comparison demonstrates the presence of relatively small areas $(<0.05)$ of open water in or near the sensor footprint, possibly in combination with increased, belowcritical vegetation density conditions (optical density $<0.8$ ), which contribute to seasonally varying biases in excess of $0.2\left(\mathrm{~m}^{3} \mathrm{~m}^{-3}\right)$ soil water content. These errors need to be addressed, either through elimination or accurate characterisation, if the soil moisture retrievals are to be used effectively in a data assimilation scheme.
\end{abstract}

\section{Introduction}

Near-surface soil moisture derived from remotely sensed low-frequency microwave emissions has the ability to improve hydrological and meteorological modelling (e.g. Koster et al., 2004; Scipal et al., 2005; Crow, 2007; Brocca et al., 2011). For example, the Land Parameter Retrieval Model (LPRM, Owe et al., 2008), a radiative transfer-based model, has demonstrated significant potential for providing estimates of land surface parameters, such as (relative) nearsurface moisture, land surface temperature (LST) and vegetation optical depth (VOD), independent of in situ observations. Satellite retrievals of these parameters may be combined with simulated and observed data in an assimilation scheme in order to generate the best possible data fields (e.g. Walker and Houser, 2001; Reichle et al., 2007; Scipal et al., 2008a). These data may then be used to initialise numerical weather predictions or land surface models, drive continuous atmospheric forcing correction or, in case of systematic error, assist in model structure development/improvement (Drusch, 2007; Brocca et al., 2010; Van Dijk and Renzullo, 2011). Key to such efforts is the error characterisation of the assimilation variable, in the particular case discussed here, the LPRM-derived soil moisture. Several studies have reported on this issue, traditionally using in situ validation for specific regions (e.g. De Jeu and Owe, 2003; Draper et al., 2009) and, more recently, employing triple collocation techniques to assess the relative error of multiple global soil moisture data sets by means of reference (Scipal et al., 2008b; Dorigo et al., 2010). Recently, an analytical solution based on error propagation in the partial derivatives of the radiative transfer 
function found, conforming to theory, increasing soil moisture retrieval error at higher VOD (Parinussa et al., 2011).

Apart from dense vegetation, conditions under which soil moisture cannot be accurately retrieved from passive microwave sensors include precipitating clouds, snow cover, frozen soil and (inland) surface water (e.g. Njoku et al., 2003; Pellarin et al., 2003; Gao et al., 2006; Owe et al., 2008). Typically, quality control masks are provided to screen data affected by these conditions. While most of these masks are dynamic and can be derived from ancillary data, the mask for open water is generally static and considers coastal areas and large continental lakes only. Due to the high dielectric constant of water, however, even a small sub-pixel fraction of open water may result in a non-negligible soil moisture overestimation (e.g. Davenport et al., 2008; Loew, 2008).

The LPRM screens data for snow and frozen surface conditions to flag those pixels where the model's LST is estimated to be at or below $273 \mathrm{~K}$ (Owe et al., 2008). Further, a mask is applied to remove those data affected by dense vegetation (VOD > 0.8), or where convergence between modelled and observed brightness temperature is considered insufficient (>0.25 K) (De Jeu et al., 2008). Additionally, in line with other global-scale coarse soil moisture data sets based on space-based microwave observations, a static mask is used to delineate coastal areas and (large) permanent inland lakes (Njoku et al., 2003; Scipal et al., 2008a). While static water bodies cause a constant positive bias and do not affect temporal patterns, temporal changes in open water fraction are not accounted for. Jones et al. (2009) released a global daily record of land surface parameters retrieved from AMSR-E, which as a first includes a dynamic open water fraction, based on $18.7 \mathrm{GHz} \mathrm{H}$ - and V-polarized brightness temperatures.

In this study, the influence of open water on soil moisture retrieval data (Owe et al., 2008; Jones and Kimball, 2010) was investigated by comparison to on-ground station observations and land surface models (LSMs) estimates for three areas in Oklahoma, USA (Fig. 1). Differences between the ground or model estimates and LPRM retrievals were further evaluated against dynamic estimates of open water fraction.

\section{Data}

\subsection{On-ground observations}

Soil moisture observations were taken from 11 stations in the Mesonet observational grid in Oklahoma, USA (Brock et al., 1995). The selected stations are all located within three areas of $4 \times 0.25^{\circ}$ lat/long grid cell size (Fig. 1), which are spatially representative of the predominant types of land cover in the area. These are both (wooded) grassland and cropland in the East, predominantly cropland in the west, and wooded grassland in the south-central area, as classified by the 1$\mathrm{km}$ global vegetation data set of the University of Maryland
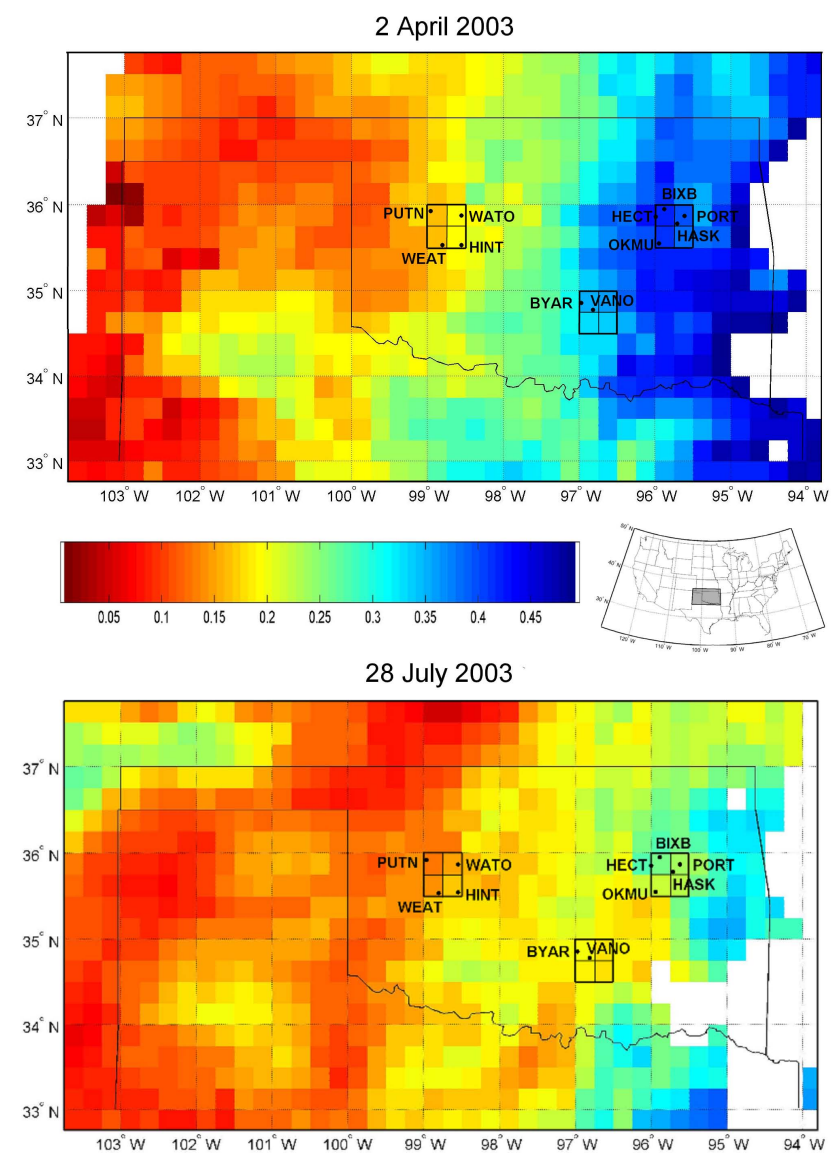

Fig. 1. AMSR-E 0.25 degree gridded absolute soil moisture $\left(\mathrm{m}^{3} \mathrm{~m}^{-3}\right.$ ) retrievals (AMSR-E VUA abs) from the Land Parameter Retrieval Model (Owe et al., 2008) for 2 April 2003 (upper panel) and 28 July 2003 (lower panel). White areas indicate grid cells outside the sensor swath (upper panel, northwest corner) or masked-out grid cells of non-convergence (east and southeast). The AMSR-E grids represented by an Oklahoma (inset, next to key) Mesonet observation stations are bold outlined.

re-sampled to a predominant vegetation type $0.125^{\circ}$ grid resolution map (http://ldas.gsfc.nasa.gov). The selection does not include an area of evergreen forest in the southeast corner of the state of Oklahoma, due to the relatively low density of ground- observation stations in this part ( 1 per $0.5^{\circ}$ grid cell). The selected $0.25^{\circ}$ grid cells all contain 1 or more stations, in which case the observations are simply averaged. If the observations of stations within a $0.25^{\circ}$ grid cell differ greatly, both the individual stations and the average are considered (e.g. stations PORT and HASK; Table 1). The 5-cm profile soil moisture content is measured using Campbell Scientific 229-L devices, made available every half hour (Illston et al., 2008). The AMSR-E overpass is at nighttime (descending orbit $\sim 01: 30$ local time (LT), i.e. 08:30 Coordinated Universal Time, UTC) and at daytime (ascending orbit $\sim 13: 30$ LT, i.e. 20:30 UTC). 


\subsection{Model estimates}

The land information system (LIS), developed at NASA Goddard Space Flight Center, is an interoperable platform capable of integrating the use of LSMs, data management techniques and high performance computing (Kumar et al., 2006). The community Noah land surface model (Ek et al., 2003) and the Community Land Model version 2:0 (CLM2) (Dai et al., 2002; Zeng et al., 2002) are two of the LSMs currently supported by LIS. Both are standalone, 1-D models and are freely available: Noah from the National Centers for Environmental Prediction (www.emc. ncep.noaa.gov/NOAH/) and CLM2 from The National Center for Atmospheric Research (www.cgd.ucar.edu/tss/clm/ distribution/clm2.1/), respectively.

The LSMs simulate a range of water- and energy balance variables, of which near-surface soil moisture is of interest for the present analysis. The models apply finite difference spatial discretisation methods and (semi-)implicit timeintegration schemes to numerically integrate the governing equations of the physical processes of the soil-vegetationsnow pack medium, including the surface energy balance equation, the Richards equation for soil hydraulics, the diffusion equation for soil heat transfer, the energy-mass balance equation for the snow pack, and equations for the conductance of canopy transpiration.

The LSMs can be applied in either coupled or uncoupled mode. In this study, the models were applied in uncoupled mode, meaning that some (atmospheric forcing) data are used as input, rather than as a dynamic model state themselves. Here, three sets of forcing data were used, i.e. the NCEP Global Data Assimilation System (GDAS), the European Centre for Medium-Range Weather Forecasts (ECMWF) and the North American Data Assimilation System (NLDAS, based on Eta model data of Mesinger, 2000, and supplemented with observation-based precipitation and radiation data as per Cosgrove et al. (2003). The forcing data are eight in total: large-scale precipitation, convective precipitation, specific humidity, surface pressure, downward shortwave solar radiation, downward thermal radiation, air temperature, and wind velocity. The temporal and spatial resolution of the NLDAS forcing is $1 \mathrm{~h}$ and $0.125^{\circ}$, while GDAS and ECMWF have a $3 \mathrm{~h}$ time step and a $0.25^{\circ}$ spatial grid (http://ldas.gsfc.nasa.gov/gldas/GLDASforcing. php). The combination of two models (Noah, CLM2) and three forcing data sets created a model ensemble of six members, of which the spread provides an indication of the range and uncertainty of modelled soil moisture involved. The Noah and CLM models were initialised with a soil moisture profile in static gravitational equilibrium and run with one full year (2003) of forcing data. The soil moisture profile at the end of the year was used as the initial soil moisture profile of the next full year run. This was repeated for the number of times it took for the soil moisture profile of consecutive runs to remain (virtually) unchanged at the end of the full year run. This soil moisture profile was subsequently used for model initialisation. The model estimates are obtained independently of the satellite soil moisture retrievals.

\subsection{Satellite observations}

Data sets were obtained of near-surface soil moisture retrievals $(\sim 2 \mathrm{~cm})$ derived from the $6.9 \mathrm{GHz}$ (C-band) and $10.7 \mathrm{GHz}$ (X-band) microwave signal from the AMSR-E instrument on board the Aqua satellite using the LPRM (Owe et al., 2008). Whilst the LPRM initially provided retrievals of absolute soil moisture (i.e. in the $0-0.5\left(\mathrm{~m}^{3} \mathrm{~m}^{-3)}\right.$ range), it currently offers a soil moisture index, which implies retrievals may be in excess of the $0.5\left(\mathrm{~m}^{3} \mathrm{~m}^{-3)}\right.$ threshold. To assess the impact of (re)scaling on the LPRM soil moisture product, both the absolute and relative retrieval are analysed for the year 2003. The AMSR-E footprint is an oval of diameter $43 \times 74 \mathrm{~km}$ and $30 \times 51 \mathrm{~km}$ at $\mathrm{C}$ - and X-band, respectively, defined as the size of the $-3 \mathrm{~dB}$ ( $50 \%$ gain) beam diameter of the radio channel ( $\mathrm{Gu}$ and England, 2007). By default, the derived soil moisture fields are re-sampled globally to a $0.25^{\circ}$ grid $(\sim 25 \mathrm{~km})$, assigning a value to a grid cell if the centroid of the footprint falls within. It is noted that this extends the nominal footprint area considered to a zone by up to $37 \mathrm{~km}$ beyond the grid cell, in case the centroid happens to plot close to the grid cell borderline. Further, as the $-3 \mathrm{~dB}$ is used as the cut-off gain, the size of the contributing area is in fact larger than the defined footprint. The implication of this is further discussed below.

A subset covering the state of Oklahoma, USA, was sampled from the global data set. The choice for this location is motivated by the availability of sets of ground-observed data (Oklahoma Mesonet, Brock et al., 1995) for the period corresponding with the satellite data and atmospheric forcing data for the model simulations (i.e. 2003).

All data contaminated by precipitating clouds were removed by visual inspection of the LPRM retrieved surface temperature fields and by comparison to ground-observed surface temperature for Oklahoma (Gouweleeuw et al., 2007). Most of the cloud-contaminating conditions occur at daytime in summer, when convection is strong. While this eliminated about $1-3 \%$ of the data set, frozen soil conditions in winter took out the bulk of the data (over $30 \%$ ) at this time of year.

\section{Methods}

First, time series of the on-ground, modelled and satellitederived top soil moisture estimates for the three areas were plotted and visually inspected to examine the level of agreement. Next, outliers were identified, inspected and, if justified, removed. As noted above, most of the outliers in the satellite-derived estimates could be related to precipitating 
Table 1. RMSE $\left(\mathrm{m}^{3} \mathrm{~m}^{-3}\right)$ of the current VUA relative soil moisture product vs. ground-observed and modelled soil moisture estimates.

\begin{tabular}{|c|c|c|c|c|c|c|c|c|c|c|}
\hline \multirow[b]{2}{*}{ RMSE } & \multirow[b]{2}{*}{ Grid/Station } & \multirow[b]{2}{*}{ MESO-NET } & \multicolumn{4}{|c|}{ CLM2 } & \multicolumn{4}{|c|}{ Noah } \\
\hline & & & ECMWF & GDAS & NLDAS & Mean & ECMWF & GDAS & NLDAS & Mean \\
\hline \multirow[t]{4}{*}{ Western area } & PUTN & 0.12 & 0.056 & 0.073 & 0.051 & 0.056 & 0.12 & 0.14 & 0.11 & 0.12 \\
\hline & WEAT & 0.11 & 0.056 & 0.075 & 0.055 & 0.056 & 0.12 & 0.14 & 0.11 & 0.12 \\
\hline & WATO & 0.072 & 0.071 & 0.064 & 0.076 & 0.065 & 0.065 & 0.080 & 0.058 & 0.067 \\
\hline & HINT & 0.064 & 0.071 & 0.066 & 0.079 & 0.066 & 0.075 & 0.094 & 0.067 & 0.078 \\
\hline \multirow[t]{5}{*}{ Eastern area } & HECT-BIXB & 0.15 & 0.17 & 0.17 & 0.19 & 0.18 & 0.12 & 0.12 & 0.12 & 0.12 \\
\hline & PORT & 0.19 & 0.19 & 0.19 & 0.22 & 0.20 & 0.14 & 0.13 & 0.15 & 0.14 \\
\hline & PORT-HASK & 0.13 & 0.19 & 0.19 & 0.22 & 0.20 & 0.14 & 0.13 & 0.15 & 0.14 \\
\hline & HASK & 0.093 & 0.088 & 0.088 & 0.107 & 0.091 & 0.070 & 0.074 & 0.068 & 0.069 \\
\hline & OKMU & 0.092 & 0.084 & 0.095 & 0.091 & 0.088 & 0.090 & 0.10 & 0.082 & 0.089 \\
\hline South-central area & BYAR-VANO & 0.14 & 0.17 & 0.17 & 0.19 & 0.18 & 0.15 & 0.13 & 0.16 & 0.14 \\
\hline
\end{tabular}

Table 2. RMSE $\left(\mathrm{m}^{3} \mathrm{~m}^{-3}\right)$ of the UoM soil moisture product vs. ground-observed and modelled soil moisture estimates.

\begin{tabular}{|c|c|c|c|c|c|c|c|c|c|c|}
\hline \multirow[b]{2}{*}{ RMSE } & \multirow[b]{2}{*}{ Grid/Station } & \multirow[b]{2}{*}{ MESO-NET } & \multicolumn{4}{|c|}{ CLM2 } & \multicolumn{4}{|c|}{ Noah } \\
\hline & & & ECMWF & GDAS & NLDAS & Mean & ECMWF & GDAS & NLDAS & Mean \\
\hline \multirow[t]{4}{*}{ Western area } & PUTN & 0.19 & 0.09 & 0.12 & 0.081 & 0.096 & 0.20 & 0.22 & 0.18 & 0.20 \\
\hline & WEAT & 0.17 & 0.083 & 0.10 & 0.070 & 0.084 & 0.19 & 0.22 & 0.18 & 0.19 \\
\hline & WATO & 0.19 & 0.079 & 0.10 & 0.068 & 0.083 & 0.18 & 0.20 & 0.17 & 0.18 \\
\hline & HINT & 0.16 & 0.080 & 0.10 & 0.067 & 0.082 & 0.19 & 0.21 & 0.18 & 0.19 \\
\hline \multirow[t]{5}{*}{ Eastern area } & HECT-BIXB & 0.14 & 0.12 & 0.13 & 0.10 & 0.12 & 0.18 & 0.18 & 0.17 & 0.18 \\
\hline & PORT & 0.14 & 0.14 & 0.14 & 0.12 & 0.13 & 0.20 & 0.20 & 0.18 & 0.20 \\
\hline & PORT-HASK & 0.21 & 0.14 & 0.14 & 0.12 & 0.13 & 0.20 & 0.20 & 0.19 & 0.20 \\
\hline & HASK & 0.27 & 0.14 & 0.14 & 0.12 & 0.13 & 0.20 & 0.20 & 0.18 & 0.20 \\
\hline & OKMU & 0.18 & 0.15 & 0.16 & 0.14 & 0.15 & 0.17 & 0.19 & 0.14 & 0.17 \\
\hline South-central area & BYAR-VANO & 0.15 & 0.11 & 0.12 & 0.096 & 0.11 & 0.13 & 0.16 & 0.12 & 0.13 \\
\hline
\end{tabular}

cloud and soil freezing conditions. Further noise or shortlived events were averaged out by applying a 14-day simple mean low-pass filter to the time series plots (Fig. 2). Next, seasonal effects were identified that could potentially cause temporal bias in the satellite retrievals, viz.: (1) the vegetation cycle; (2) land surface temperature; and (3) open water. This is explored in more detail in the Discussion section. With regard to (3), the effect of the open water fraction (OWF) in the passive microwave footprint was assessed in three ways, viz.: (a) using $1 \mathrm{~km}$ 16-day composite MODIS reflectance data; (b) from an open water fraction estimate, based on 18.7 GHz H- and V-polarized AMSR-E brightness temperature (Jones and Kimball, 2010), made available by the University of Montana (hereafter referred to as $\mathrm{OWF}_{\mathrm{UoM}}$ ); and (c) the difference between satellite-observed and modelled brightness temperature, inverting LPRM.

The approach to map open water extent from MODIS data computes an Open Water Index (OWI) from the Nadir-BRDF Adjusted Reflectance (NBAR) product (MCD43B4). This MODIS product provides a $1 \mathrm{~km}$ 16-day composite of land surface reflectance, corrected for Bidirectional Reflectance Distribution Function (BRDF) and atmospheric affects. The OWI is computed as the difference of the Global Vegetation Moisture Index (GVMI) and the Enhanced Vegetation Index
(EVI), if EVI $<0.2$. If EVI $\geq 0.2, \mathrm{OWI}=0$ (Guerschman et al., 2008). Validation against higher resolution Landsat mapping suggests this method performs as well as or better than other commonly used methods (Guerschman et al., 2009). The OWF $\mathrm{OMDIS}_{\text {is }}$ computed as the number of $1 \mathrm{~km}$ pixels of OWI $>0$ in a grid cell, divided by the total number of pixels.

The third method calculates an open water fraction by solving the following equation for $\mathrm{OWF}_{\mathrm{LPRM}}$, which apportions the overall observed satellite brightness temperature proportionately between the open water and the land surface:

$$
\begin{aligned}
T_{\mathrm{b} \text { sat }} & =\left(1-\mathrm{OWF}_{\mathrm{LPRM}}\right) \cdot T_{\mathrm{b} \text { obs/LSM }} \\
& +\mathrm{OWF}_{\mathrm{LPRM}} \cdot T_{\mathrm{b} \text { water }}
\end{aligned}
$$

where $T_{\mathrm{b} \text { sat }}$ is the satellite-observed brightness temperature, $T_{\mathrm{b} \text { obs/LSM }}$ is the brightness temperature calculated from LSM simulated or ground-observed soil moisture and $T_{\mathrm{b}}$ water is the brightness temperature of water.

Both $T_{\mathrm{b} \text { obs/LSM }}$ and $T_{\mathrm{b} \text { water }}$ are calculated by inverting the LPRM and re-inserting retrieved LST and optical density values. To calculate $T_{\mathrm{b} \text { water }}$, the absolute value of the dielectric constant of water (80) is inserted into the model. Thus, the product of $\mathrm{OWF}_{\mathrm{LPRM}}$ and $T_{\mathrm{b} \text { water }}$ is used to account for the difference between $T_{\mathrm{b} \text { sat }}$ and $T_{\mathrm{b} \text { obs/LSM }}$, where $T_{\mathrm{b} \text { obs/LSM ex- }}$ ceeds $T_{\mathrm{b} \text { sat }}$. 

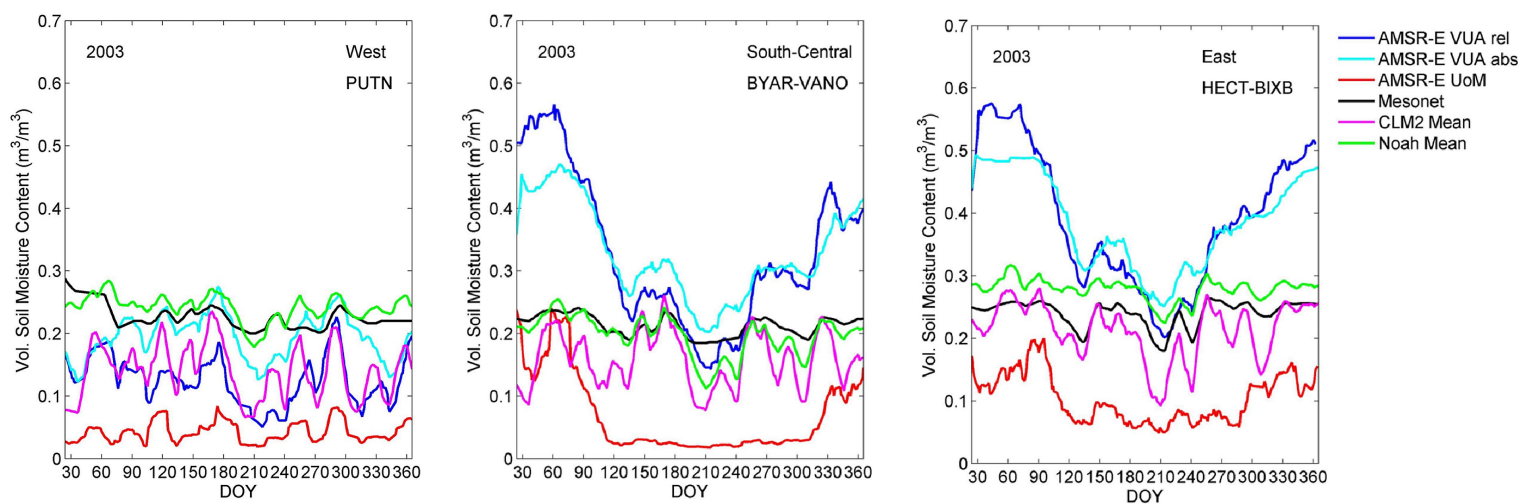

Fig. 2. AMSR-E derived, ground-observed and simulated soil moisture for $0.25^{\circ}$ grid cells in the Western (PUTN), South-Central (BYARVANO) and Eastern Oklahoma area (HECT-BIXB) (low-pass filter 14 days).

\section{Results}

\subsection{Comparison of on-ground, modelled and satellite-derived soil moisture}

Figure 1 shows two examples of $0.25^{\circ}$ gridded maps of AMSR-E-derived absolute soil moisture using LPRM (hereafter referred to as Vrije Universiteit Amsterdam, VUA) of Oklahoma at nighttime (descending orbit) for 2 April and 28 July 2003 , together with the three areas of $4 \times 0.25^{\circ}$ cell grid size, within which ground-observed data are sampled. The early spring image shows a distinct east-west gradient (2 April), which is persistent throughout the year, albeit less pronounced in summer, as shown for 28 July. Figure 2 illustrates the dynamics of this east-west gradient for the year 2003, plotted together with AMSR-E VUA rel, the current relative VUA retrieval product, and AMSR-E retrievals from Jones and Kimball (2010) (hereafter referred to as University of Montana, UoM), ground-observed and mean modelled soil moisture for the $0.25^{\circ}$ grid cells in the western area (PUTN), south-central area (BYAR-VANO) and eastern area (HECT-BIXB). In the eastern and south-central areas, both AMSR-E VUA abs and AMSR-E VUA rel soil moistures are much higher than all the other estimates, most notably in the first and last three months of the year. Unsurprisingly, the AMSR-E VUA rel retrieval shows a larger range than the AMSR-E VUA abs product for these areas. The seasonal pattern, however, is virtually identical. This seems to indicate that the (re)scaling of the VUA product does not significantly affect the observed pattern. The AMSR-E UoM retrievals show the lowest soil moisture estimated for all areas, with the exception of the start of the year in the south-central area. While the satellite-derived soil moisture data sets make use of the same sensor, the UoM applies a different method to solve the microwave radiative transfer function for land surface variables, using a combination of multi-frequency polarizations and ratios (Jones and Kimball, 2010). Additionally, it employs an open water fraction derived from higher frequency AMSR-E data to correct for positive bias. Some seasonality is also present in the UoM retrievals in the southcentral and eastern area, albeit less pronounced and at a lower level than in the VUA retrievals. Tables 1 and 2 indicate RMSE for the UoM retrievals vs. ground-observed and modelled soil moisture is consistently higher than the RMSE for the VUA product in the western area, while it is alternately higher and lower in the other two areas. The UoM product compares best to the CLM2 simulations, which reproduce relatively dry time series of soil moisture with a high dynamic range (Fig. 2). This is explained by the shallow top soil layer in the model adjusted to $\sim 2 \mathrm{~cm}$ to match the AMSR-E sampling depth. The Noah model structure stipulates a soil profile with fixed depths of its 10 layers (Ek et al., 2003). The depth of the top soil layer is fixed at $10 \mathrm{~cm}$, prompting higher average moisture content with a lower dynamic range. The Mesonet observations, taken at $5 \mathrm{~cm}$ depth, mostly plot close to the Noah simulations, although they deviate slightly more in the eastern area. In the western area, the AMSR-E products plot closest to the CLM2 simulation, in agreement with the comparable sampling depth.

\subsection{Independent estimation of OWF using MODIS imagery}

Figure 3 shows two RGB false colour maps (band 7, 2, and 1) of Oklahoma depicting MODIS 16-day composite reflectance data (MCD43B4). The 16-day composites include the dates of the daily soil moisture retrieval maps in Fig. 1 (i.e. 22 March-6 April 2003 (upper panel) and 12-28 July 2003). Pixels of OWI $>0$ are coloured blue, representing mostly dammed lakes/reservoirs and the wider $(>1 \mathrm{~km})$ stretches of streams. At a glance, open water extent appears to be larger in March-April, albeit only marginally.

Figure 4 shows times series of $\mathrm{OWF}_{\text {MODIS }}$ for the $0.25^{\circ}$ grid cells in the Western, South-Central and Eastern Oklahoma area (as labelled in Fig. 3) together with OWF UoM. As noted earlier, the AMSR-E $6.9 \mathrm{GHz}$ and $10.7 \mathrm{GHz}$ footprint 

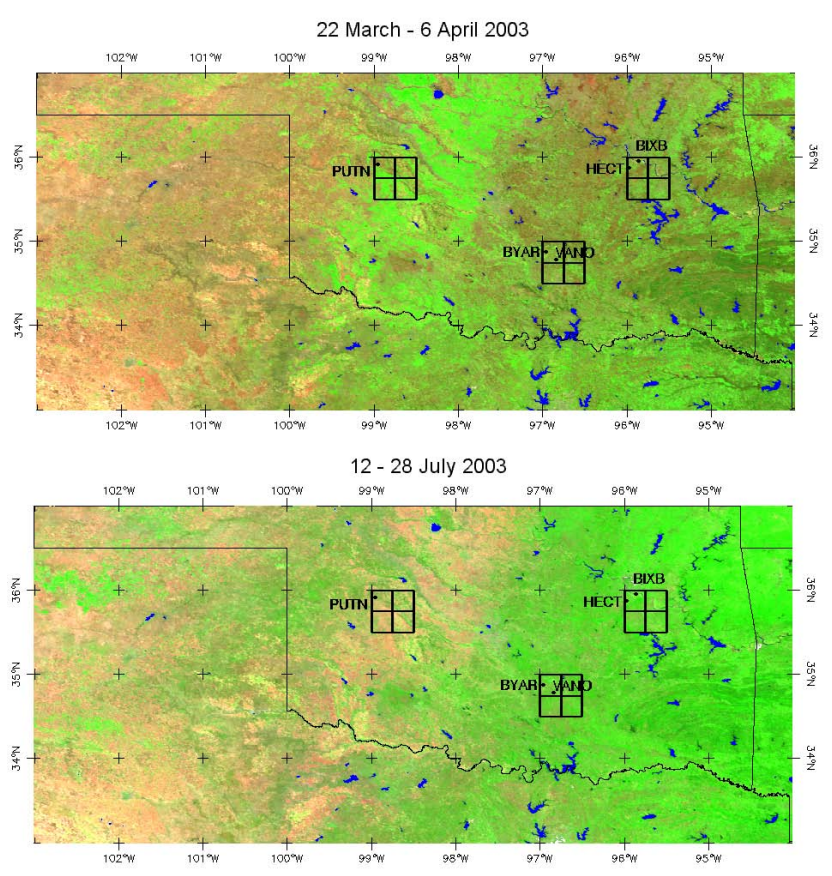

Fig. 3. RGB false colour maps (band 7, 2, and 1) of Oklahoma of $1 \mathrm{~km} \mathrm{16-day} \mathrm{composite} \mathrm{MODIS} \mathrm{reflectance} \mathrm{data} \mathrm{(MCD43B4)}$ overprinted with the Open Water Index (OWI) map for 22 March6 April 2003 (upper panel) and 12-28 July 2003 (lower panel). Also depicted are the three areas in the Western (PUTN), South-Central (BYAR-VANO) and Eastern Oklahoma area (HECT-BIXB). Pixels of OWI $>0$ are coloured blue.

sizes are substantially larger than $0.25^{\circ}$, so OWF also computed for larger grid cells centred in the $0.25^{\circ}$ grid cell. Figure 4 shows OWFMODIS remains about constant in the western area, although levels vary slightly with grid cell size. The Eastern area shows a marked seasonal change in $\mathrm{OWF}_{\text {MODIS }}$, which increases in level and variation with grid cell size up to $1.25^{\circ}$. OWF $\mathrm{UoM}_{\mathrm{M}}$ falls somewhere between the $0.75-1.5^{\circ} \mathrm{OWF}_{\mathrm{MODIS}}$ and generally reflects a corresponding seasonal pattern, absent in the other two areas. Considering $\mathrm{OWF}_{\mathrm{UoM}}$ is based on the $18.7 \mathrm{GHz}$ signal of $27 \times 16 \mathrm{~km}$ footprint, one would expect a better agreement with the

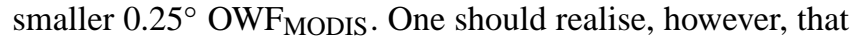
the OWF estimates are based on independent data and unrelated methods. Despite that, they show an agreement in level and pattern, in that OWF is absent in the western and southcentral area and present and dynamic in the east. By contrast, in the south-central area, neither MODIS nor UoM (Fig. 4, middle panel) indicates the presence of an open water fraction to account for the observed LPRM soil moisture retrieval overestimation (Fig. 2, middle panel), with the exception of a small increase in $\mathrm{OWF}_{\mathrm{UoM}}$ at around day 60 . This may be explained by the different passive microwave frequencies, and hence, spatial resolutions, involved. The 6.9 and $10.7 \mathrm{GHz}$ soil moisture retrieval occupies the larger footprint, an oval of diameter $43 \times 74 \mathrm{~km}$ and $30 \times 51 \mathrm{~km}$ (and beyond), respectively, and is prone to signal smearing, when re-sampled to a 0.25 degree grid, in this particular case from the East. This is much less the case for the smaller $18.7 \mathrm{GHz}$ open water fraction footprint of $27 \times 16 \mathrm{~km}$, which falls almost entirely within the 0.25 degree grid.

\subsection{Estimation of OWF by inversion of LPRM}

Figure 5 shows OWF $_{\text {LPRM }}$ calculated for the grid cells shown in Figs. 2 and 4, in case the AMSR-E VUA products exceed the modelled or ground-observed soil moisture estimate. As a result, it is calculated for the drier CLM2 simulations in the western area only, reflecting an alternating pattern of dry down and wetting up in the shallow, 2-cm model, top soil layer. In the eastern and south-central area, the alternating OWF $_{\text {LPRM }}$ pattern is set on top of a more seasonal variation

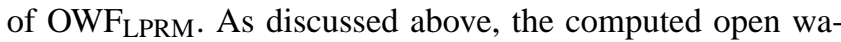
ter fraction in the south-central area is presumably the result of an artefact caused by signal smearing of the relatively large $6.9 \mathrm{GHz}$ satellite footprint over a 0.25 degree grid. The $\mathrm{OWF}_{\mathrm{UoM}}$ in the Eastern area corresponds remarkably well to $\mathrm{OWF}_{\mathrm{LPRM}}$, especially the fraction calculated for CLM2. In summer, OWF phase with $\mathrm{OWF}_{\mathrm{UoM}}$. This could indicate additional bias due to another source, e.g. dense vegetation. In the Eastern area, however, the computed $\mathrm{OWF}_{\mathrm{LPRM}}$ indicates that a small fraction $(<0.05)$ of open water in the satellite observation footprint alone may cause a large positive bias in the soil moisture product $\left(>0.2 \mathrm{~m}^{3} \mathrm{~m}^{-3}\right)$.

\section{Discussion}

The single year analysis presented here argues that the seasonally varying extent of water bodies can explain most of the anomaly between ground observations and model estimates of near-surface soil moisture on the one hand, and LPRM-based AMSR-E satellite retrievals on the other. Of the three seasonal effects identified as potentially causing bias in the satellite retrievals, viz.: the vegetation cycle, LST and varying open water extent, the latter is considered the most plausible. This is discussed in more detail below.

Most of the Oklahoma land surface cover consists of sparse vegetation, i.e. grassland/ cropland in the west and wooded grassland in the east. An exception is a patch of forest in the southeast corner of Oklahoma, which is not included in the present analysis. Although saturation of the microwave signal is significant over dense vegetation, previous studies have shown good agreement between the microwave vegetation signal (VOD) and independent observations, such as the Normalised Difference Vegetation Index (NDVI), and the derived soil moisture with shallow field measurements in varying environments (e.g. Owe et al., 2001; De Jeu and Owe, 2003; Draper et al., 2009). Figure 6 shows the NDVI, 

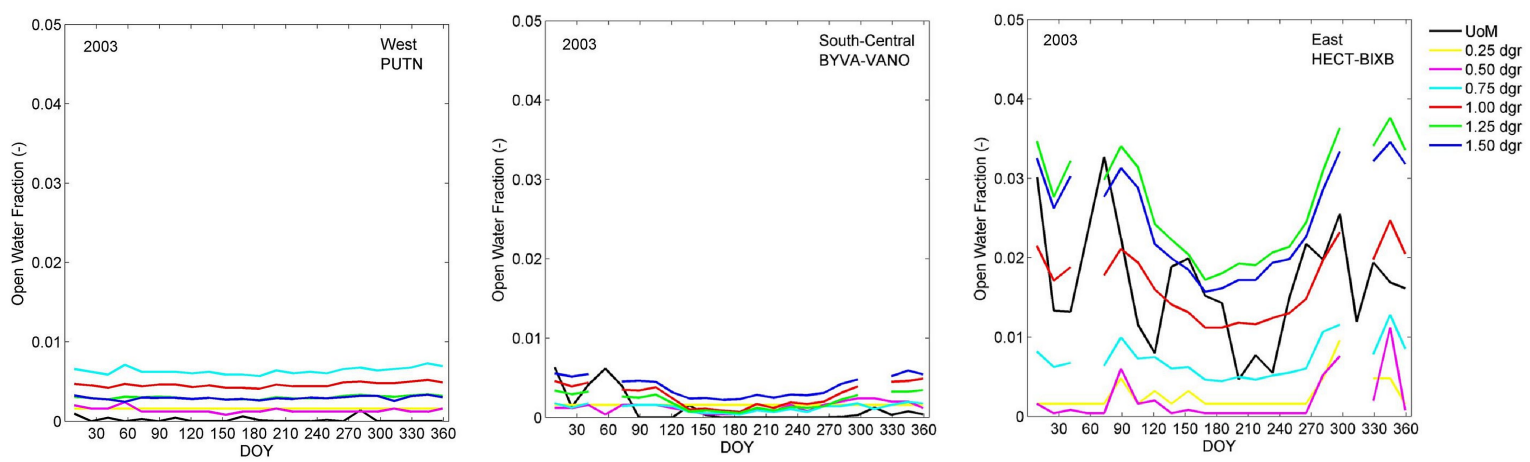

Fig. 4. Time series of the MODIS-derived Open Water Fraction for the $0.25^{\circ}$ grids cells in the Western, South-Central and Eastern Oklahoma area for increasing grid cell sizes, together with the UoM open water fraction.
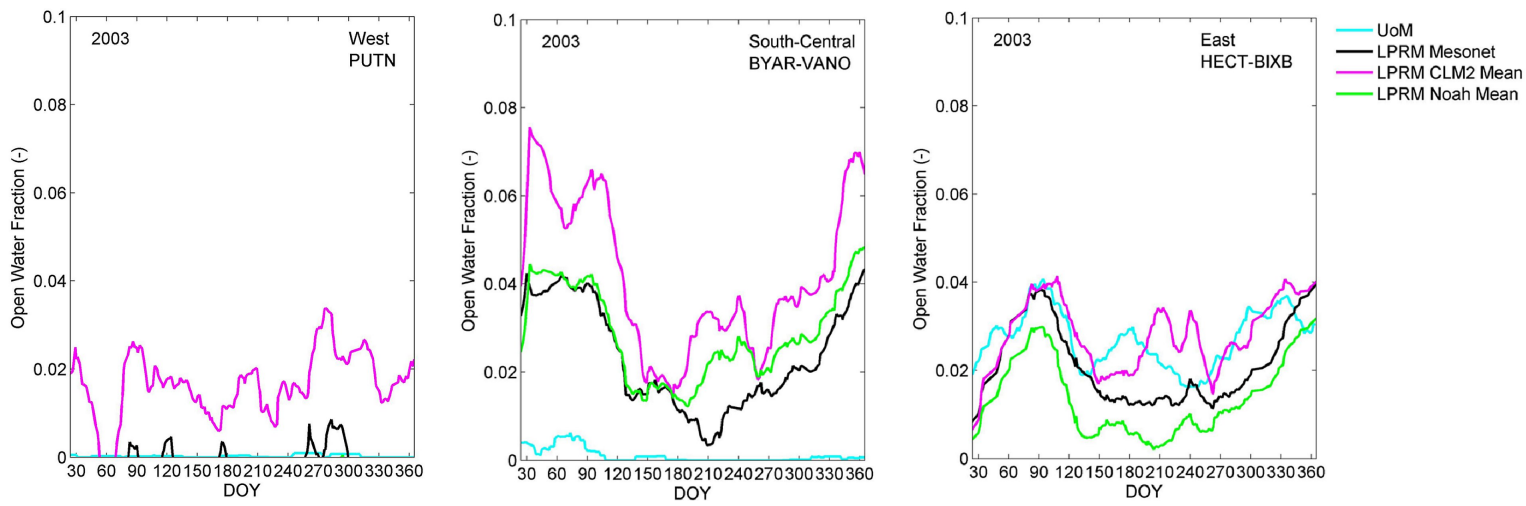

Fig. 5. Time series of the Open Water Fraction calculated with the LPRM, together with the OWF $\mathrm{UoM}_{\text {, for }}$ the $0.25^{\circ}$ grids cells in the Western, South-Central and Eastern Oklahoma area (low-pass filter 14 days).

together with the VUA (relative and absolute, 1 frequency) and UoM ( 3 frequencies) optical vegetation indices for the three areas. The NDVI peaks early and, again, late in the year in the western area. This is somewhat faintly reflected in the VUA VOD, which agrees better with the NDVI in the southcentral and eastern area, although it lacks the dynamic range. The UoM VOD is relatively flat and comparatively low in the south-central and eastern area. Following Parinussa et al. (2011), the relatively high VUA VOD peak values in all three areas (0.6-0.7) suggest a soil moisture error estimation of $0.1-0.13\left(\mathrm{~m}^{3} \mathrm{~m}^{-3}\right)$ for $6.9 \mathrm{GHz}$ and $0.15-0.20\left(\mathrm{~m}^{3} \mathrm{~m}^{-3}\right)$ for $10.7 \mathrm{GHz}$. While these estimated errors account for more than half of the observed differences in soil moisture estimates in value, the seasonal dynamic of the VOD time series is in reverse phase, i.e. the highest soil moisture bias coincides with the lowest VOD estimates. An increased VOD value, therefore, may add to the positive (or negative) bias in the soil moisture retrieval without fully accounting for it.

Figure 2 shows that the overestimation of satellite-derived soil moisture estimates in the eastern and south-central area occurs in the colder part of the year, i.e. winter/spring and autumn/winter. The LPRM (Owe et al., 2008) provides LST from $37 \mathrm{GHz}$ brightness temperature observations, which is used to normalise the lower-frequency brightness temperature $(6.6 \mathrm{GHz}$ and $10.7 \mathrm{GHz})$ for emissivity. In summer during the daytime, the LST may well exceed the temperature of the deeper emitting soil layer in the lower frequencies, especially in dry conditions. If uncorrected, this may result in an underestimation of the emissivity, i.e. an overestimation of the satellite-derived soil moisture estimate. Conversely, in the cold season, it may lead to underestimation of the soil moisture estimate. Hence, a LST bias would have the inverse effect of what is observed.

Until recently, methods to correct footprints for dynamic water body effects have not been considered feasible or costeffective on a routine global basis. This study argues temporal, regional variations in OWF could have a profound effect on these soil moisture retrievals. Temporal variations in OWF derived from 18.7 GHz AMSR-E observations (Jones and Kimball, 2010) agree reasonably well with independently obtained estimates, using the MODIS optical bands and through LPRM inversion. Even better agreement is achieved when considering that the re-sampling of $6.9 / 10.7 \mathrm{GHz}$ footprint data (of $43 \times 74 \mathrm{~km} / 30 \times 51 \mathrm{~km}$ size) into a 0.25 degree grid has led to considerable signal smearing in the LPRMbased soil moisture retrievals. 

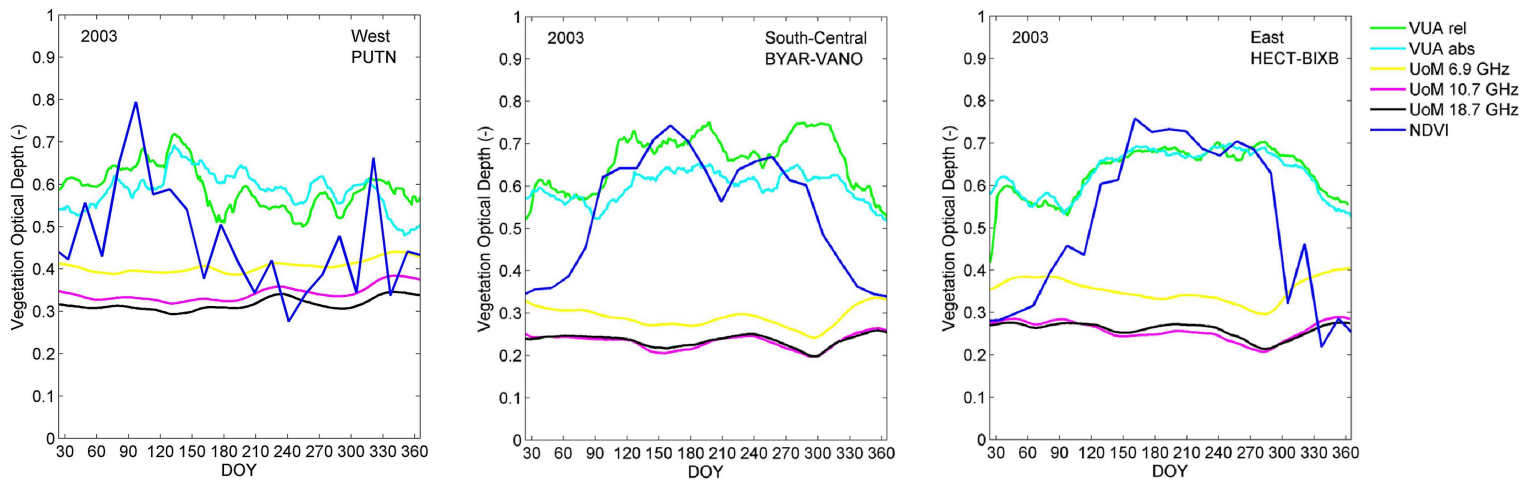

Fig. 6. The AMSR-E UoM and VUA VOD retrievals (low-pass filter 30 days), together with area-averaged NDVI.
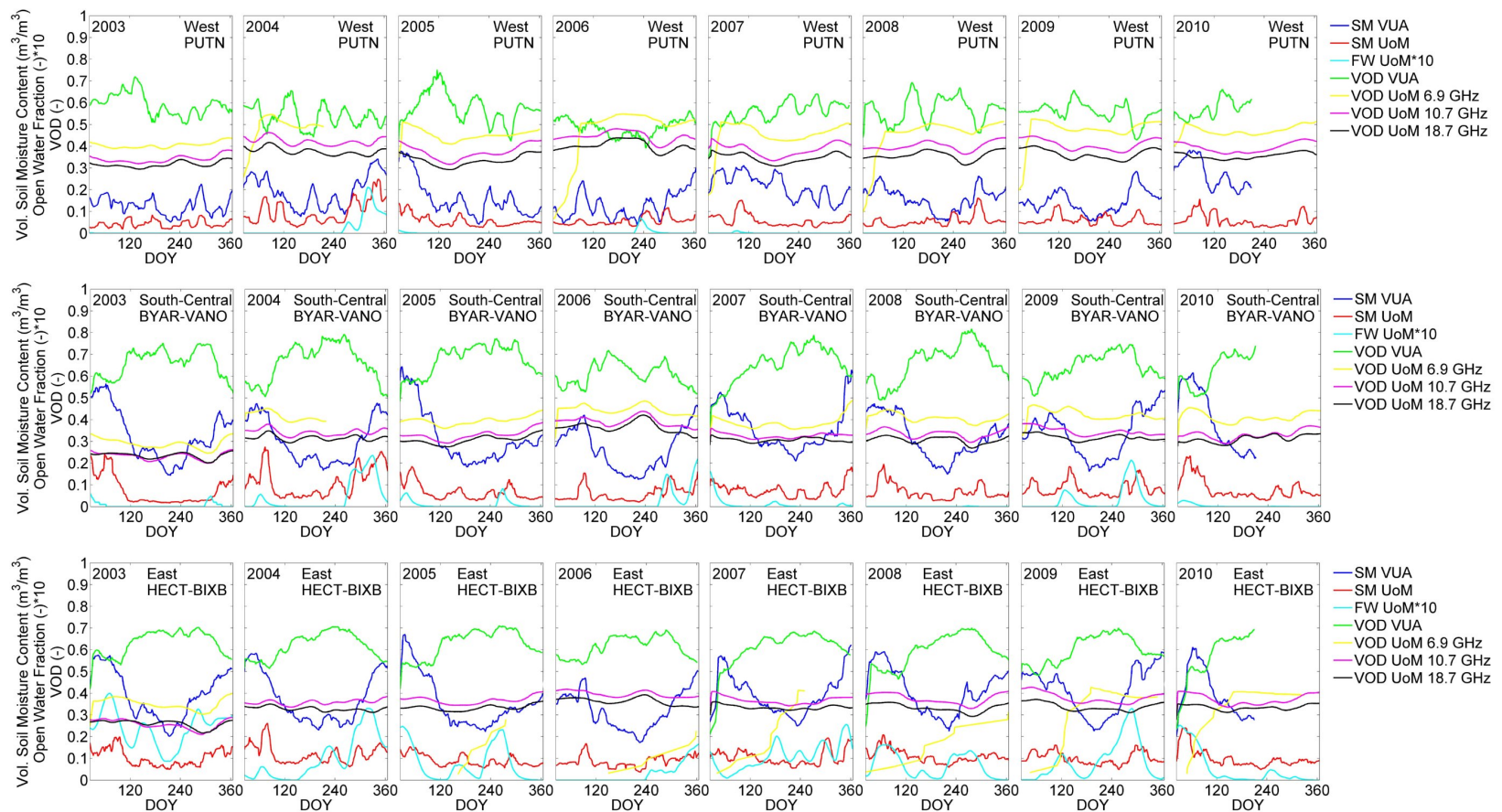

Fig. 7. Time series from 2003 to (mid-) 2010 of the current VUA rel and UoM soil moisture and VOD products, together with the smoothed UoM OWF (30-day moving median filter), for the Western (top), South-Central (middle) and Eastern (lower) Oklahoma areas.

Figure 7 shows the time series from 2003 to 2010 of UOM, and to mid-2010 of the current VUA soil moisture and VOD products. Although on-ground soil moisture observations and model simulations have not been analysed, the general patterns observed for 2003 are replicated in the longer time series. The south-central and eastern areas (two lower panels) show a seasonal positive bias in VUA soil moisture, which for the latter area coincides with an increase of open water fraction most of times, a notable exception is the first half of 2006, for which no $\mathrm{OWF}_{\mathrm{UoM}}$ data were available. From the time series for the Eastern area (lower panel), however, it appears that an $\mathrm{OWF}_{\mathrm{UoM}}$ increase is not equally proportional to a positive bias of VUA soil moisture over time all the time. This could indicate an interaction with, or possibly reinforcement of, soil moisture retrieval error at higher VOD. The open water fraction calculated through LPRM inversion for 2003, however, agrees well with the independently obtained fractions, which indicates that it alone may account for the observed soil moisture retrieval bias. Previous synthetic studies (e.g. Davenport et al., 2008; Loew, 2008) suggest that ignoring an open water fraction of 0.05 in the retrieval can leads to a bias of about $0.05-0.1\left(\mathrm{~m}^{3} \mathrm{~m}^{-3}\right)$. The larger bias in proportion to the open water fraction observed in the longer time series using actual satellite observations, therefore, may represent an integrated error, caused by (an interaction of) open water, high vegetation density, etc. However, 
as mentioned earlier, the times series in Fig. 7 show VOD (and hence the associated soil moisture retrieval error) in reverse phase with the observed positive soil moisture bias.

Pellarin et al. (2003), using L-band passive microwave observations, estimated that more than a third of the Earth's terrestrial surface has $>0.01$ open water, defined in that case as persistent open water. Open water area, however, is by no means static and may vary for shorter or longer periods of time through e.g. flooding, irrigation, and the seasonal recharge and drying of dammed lakes and wetlands.

The soil moisture missions by ESA (SMOS) and NASA (SMAP) that are currently in progress have set a target accuracy of $\pm 0.04\left(\mathrm{~m}^{3} \mathrm{~m}^{-3}\right)$. To achieve this, constant and seasonally varying extent of open water within the footprint will need to be identified and corrected for in the retrieval. This study provides an indication that higher frequency AMSR-E data provide sufficient spatial resolution to correct for open water fraction contribution on a 0.25 degree grid. On higher spatial resolutions $(500 \mathrm{~m}-1 \mathrm{~km})$, standard MODIS reflectance products are suitable for further verification. Alternatively, it has been shown that high-resolution active radar observations are well suited for open water mapping (Wagner et al., 2007; Ticehurst et al., 2009).

Taken together, it would seem that strong gains in the quality and error characterisation of passive microwave soil moisture retrievals can be made by a combination of assimilating remote sensing observations of open water area and more sophisticated signal re-sampling approaches (e.g. Gu and England, 2007).

\section{Conclusions}

Open water has a strong passive microwave signature and therefore can produce positive biases in top soil moisture content estimated from passive microwave remote sensing. Seasonal variations in the fraction of open water may further complicate the agreement and accuracy of top soil moisture retrievals. The magnitude of this effect was investigated using top soil moisture estimates for $0.25^{\circ}$ grid cells in Oklahoma, derived from on-ground station observations, land surface models, and the AMSR-E passive microwave satellite instrument. Differences between the ground or model estimates and remote sensing retrievals were compared to dynamic estimates of open water fraction retrieved from a global daily record based on higher frequency AMSR-E data (Jones and Kimball, 2010), derived from MODIS (Guerschman et al., 2009) and calculated through LPRM inversion. The comparison indicates that seasonally varying biases in excess of $0.2\left(\mathrm{~m}^{3} \mathrm{~m}^{-3}\right)$ soil water content can be attributed to the presence of relatively small areas $(<0.05)$ of open water in the (nominal) footprint, possibly in combination with (or enhanced by) higher, but below-critical vegetation density conditions (optical density $<0.8$ ). Given the widespread distribution of small water bodies over the Earth's land surface and the large satellite footprint, it is plausible that more often than not current soil moisture products have considerable positive bias and systematic noise. It is shown that retrievals can be improved by considering temporal observations of open water area, but the source of the satellite signal needs to be considered when re-sampling into spatial grid resolutions that are smaller than the source area.

\section{Supplementary material related to this article is available online at: http://www.hydrol-earth-syst-sci.net/ 16/1635/2012/hess-16-1635-2012-supplement.zip.}

Acknowledgements. This research is funded under the Water Information Research and Development Alliance (WIRADA) between CSIRO and the Bureau of Meteorology (BoM), Project 3.1 "Water Resources Assessment and Water Use Accounting".

Edited by: Y. Liu

\section{References}

Brocca, L., Melone, F., Moramarco, T., Wagner, W., Naeimi, V., Bartalis, Z., and Hasenauer, S.: Improving runoff prediction through the assimilation of the ASCAT soil moisture product, Hydrol. Earth Syst. Sci., 14, 1881-1893, doi:10.5194/hess-141881-2010, 2010.

Brocca, L., Moramarco, T., Melone, F., Wagner, W., Hasenauer, S., and Hahn, S.: Assimilation of surface and root-zone ASCAT soil moisture products into rainfall runoff modelling, IEEE T. Geosci. Remote, PP, 1-14, doi:10.1109/TGRS.2011.2177468, 2011

Brock, F. V., Crawford, K. C., Elliott, R. L., Cuperus, G. W., Stadler, S. J., Johnson, H. L., and Eilts, M. D.: The Oklahoma Mesonet: A Technical Overview, J. Atmos. Ocean.-Tech., 12, 5-19, 1995.

Cosgrove, B. A., Lohmann, D., Mitchell, K. E., Houser, P. R., Wood, E. F., Schaake, J. C., Robock, A., Marshall, C., Sheffield, J., Duan, Q., Luo, L., Higgins, R. W., Pinker, R. T., Tarplay, J. D., and Meng, J.: Real-time and retrospective forcing in the North American Land Data Assimilation Sytsem (NLDAS) project, J. Geophys. Res., 108, 8842-8854, 2003.

Crow, W. T.: A novel method for quantifying value in spaceborne soil moisture retrievals, J. Hydrometeorol., 8, 56-67, 2007.

Dai, Y., Zeng, X., Dickinson, R. E., Baker, I., Bonan, G., Bosilovich, M., Denning, S., Dirmeyer, P., Houser, P., Niu, G., Oleson, K., Schlosser, A., and Yang, Z.-L.: The Common Land Model (CLM), B. Am. Meteorol. Soc., 84, 1013-1023, 2002.

Davenport, A. J., Sandells, M. J., and Gurney, R. J.: The effects of scene heterogeneity on soil moisture retrieval from passive microwave data, Adv. Water Resour., 31, 1494-1502, 2008.

De Jeu, R. A. M. and Owe, M.: Further validation of a new methodology for surface moisture, and vegetation optical depth retrieval, Int. J. Remote Sens., 24, 4559-4578, 2003.

De Jeu, R. A. M., Wagner, W., Holmes, T., Dolman, H., van de Giesen, N. C., and Friesen, J.: Global Soil moisture patterns observed by space borne microwave radiometers and scatterometers, Surv. Geophys., 29, 399-420, 2008. 
Dorigo, W. A., Scipal, K., Parinussa, R. M., Liu, Y. Y., Wagner, W., de Jeu, R. A. M., and Naeimi, V.: Error characterisation of global active and passive microwave soil moisture datasets, Hydrol. Earth Syst. Sci., 14, 2605-2616, doi:10.5194/hess-14-26052010, 2010.

Draper, C. S., Walker, J. P., Steinle, P. J., de Jeu, R. A. M., and Holmes, T. R. H.: An evaluation of AMSR-E Derived Soil Moisture over Australia, Remote Sens. Environ., 113, 703-710, 2009.

Drusch, M.: Initializing numerical weather prediction models with satellite-derived surface soil moisture, Data assimilation experiments with ECMWF's Integrated Forecast System and the TMI soil moisture data set, J. Geophys. Res.-Atmos., 112, D03102, doi:10.1029/2006JD007478, 2007.

Ek, M. B., Mitchell, K. E., Lin, Y., Rogers, E., Grunmann, P., Koren, V., Gayno, G., and Tarpley, J. D.: Implementation of Noah land-surface model advances in the NCEP operational mesoscale mesoscale Eta model, J. Geophys. Res., 108, 8851, doi:10.1029/2002JD003296, 2003.

Gao, H., Wood, E. F., Jackson, T. J., Drusch, M., and Bindlish, R.: Using TRMM/TMI to retrieve surface soil moisture over the Southern United States from 1998 to 2002, J. Hydrometeorol., 7, 23-38, doi:10.1175/JHM473.1, 2006.

Gouweleeuw, B. T., Owe, M., and Holmes, T.: AMSR-E surface temperature retrievals: the potential for LSM data assimilation, in: MODSIM 2007 International Congress on Modelling and Simulation. Modelling and Simulation Society of Australia and New Zealand, edited by: Oxley, L. and Kulasiri, D., December 2007, 1709-1715, ISBN:978-0-9758400-47, available at: http://mssanz.org.au/MODSIM07/papers/27_s28/ AMSR-E_s28_Gouweleeuw_.pdf, 2007.

$\mathrm{Gu}, \mathrm{H}$. and England, A. W.: AMSR-E data resampling with near-circular synthesized footprint shape and noise/resolution tradeoff study, IEEE T. Geosci. Remote, 45, 3193-3203, doi:10.1109/TGRS.2007.895412, 2007

Guerschman, J. P., Van Dijk, A. I. J. M., McVicar, T., Van Niel, T., Li, L., and Liu, Y.: Water Balance estimates from satellite observations over the Murray-Darling Basin, Report to the Australian Government from the CSIRO Murray-Darling Basin Sustainable Yields Project, CSIRO: Water for a Healthy Country National Research Flagship, 2008.

Guerschman J. P., Byrne, G., González-Orozco, C., Van Dijk, A. I. J. M., Lymburner, L., Dyce, P., and Ticehurst, C.: Continental estimation of sub-pixel standing water fractions using the MODIS sensors: method development and potential application for water accounting and assessment in Australia, in: 18th World IMACS Congress and MODSIM09 International Congress on Modelling and Simulation, edited by: Anderssen, R. S., Braddock, R. D., and Newham, L. T. H., Modelling and Simulation Society of Australia and New Zealand and International Association for Mathematics and Computers in Simulation, July 2009, p. 3718, ISBN:978-0-9758400-7-8, available at: http://www.mssanz.org. au/modsim09/I10/guerschman.pdf, 2009.

Illston, B. G., Basara, J. B., Fischer, D. K., Elliott, R. L., Fiebrich, C., Crawford, K. C., Humes, K., and Hunt, E.: Mesoscale Monitoring of Soil Moisture Across a Statewide Network, J. Atmos. Ocean.-Tech., 25, 167-182, 2008.

Jones, L. A. and Kimball, J. S.: Daily Global Land Surface Parameters Derived from AMSR-E, version 1.2, 2003-2010, Boulder, Colorado USA: National Snow and Ice Data Center, Digital me- dia, available at: http://nsidc.org/data/nsidc-0451.html (last access: December 2011), 2010.

Jones, L. A., Kimball, J. S., Podest, E., McDonald, K. C., Chan, S. K., and Njoku, E. G.: A method for deriving land surface moisture, vegetation, and open water fraction from AMSRE, Int. Geosci. Remote Se., 13-17 July, Cape Town, South Africa, 2009.

Koster, R. D., Suarez, M. J., Liu, P., Jambor, U., Berg, A. A., Kistler, M., Reichle, R. H., Rodell, M., and Famiglietti, J.: Realistic initialisation of land surface states: Impacts on subseasonal forecast skill, J. Hydrometeorol., 5, 1049-1063, 2004.

Kumar, S. V., Peters-Lidard, C. D., Tian, Y., Houser, P. R., Geiger, J., Olden, S., Lighty, L., Eastman, J. L., Doty, B., Dirmeyer, P., Adams, J., Mitchell, K., Wood, E. F., and Sheffield, J.: Land Information System - An Interoperable Framework for High Resolution Land Surface Modeling, Environ. Modell. Softw., 21, 1402-1415, 2006.

Loew, A.: Impact of surface heterogeneity on surface soil moisture retrievals from passive microwave data at the regional scale: The Upper Danube case, Remote Sens. Environ., 112, 231-248, 2008.

Mesinger, F.: Numerical Methods: The Arakawa approach, horizontal grid, global, and limited-area modeling. General Circulation Model Development: Past, Present and Future, edited by: Randall, D. A., International Geophysics Series, 70, Academic Press, 373-419, 2000.

Njoku, E. G., Jackson, T., Lakshmi, V., Chan, T., and Nghiem, S. V.: Soil moisture retrieval from AMSR-E, IEEE T. Geosci. Remote, 41, 215-229, doi:10.1109/TGRS.2002.808243, 2003.

Owe, M., De Jeu, R. A. M., and Walker, J. P.: A methodology for surface soil moisture and vegetation optical depth retrieval using the microwave polarization difference index, IEEE T. Geosci. Remote, 39, 1643-1654, 2001.

Owe, M., de Jeu, R., and Holmes, T.: Multisensor historical climatology of satellite-derived global land surface moisture, J. Geophys. Res., 113, F01002, doi:10.1029/2007JF000769, 2008.

Parinussa, R., Meesters, A., Liu, Y., Dorigo, W., Wagner, W., De Jeu, R.: Error estimates for near-real-time satellite soil moisture as derived from the Land Parameter Retrieval Model, IEEE Geosci. Remote S., 8, 779-783, 2011.

Pellarin, T., Wigneron, J., Calvet, J., and Waldteufel, P.: Global soil moisture retrieval from a synthetic L-band brightness temperature data set, J. Geophys. Res., 108, 4364, doi:10.1029/2002JD003086, 2003.

Reichle, R. H., Koster, R. D., Liu, P., Mahanama, S. P. P., Njoku, E. G., and Owe, M.: Comparison and assimilation of global soil moisture retrievals from the Advanced Microwave Scanning Radiometer for the Earth Observing System (AMSR-E) and the Scanning Multichannel Microwave Radiometer (SMMR), J. Geophys. Res., 112, D09108, doi:10.1029/2006JD008033, 2007.

Scipal, K., Scheffler, C., and Wagner, W.: Soil moisture-runoff relation at the catchment scale as observed with coarse resolution microwave remote sensing, Hydrol. Earth Syst. Sci., 9, 173-183, doi:10.5194/hess-9-173-2005, 2005.

Scipal, K., Drusch, M., and Wagner, W.: Assimilation of a ERS scatterometer derived soil moisture index in the ECMWF numerical weather prediction system, Adv. Water Resour., 31, 1101-1112, 2008a.

Scipal, K., Holmes, T., De Jeu, R. A. M., Naeimi, V., and Wagner, W.: A possible solution for the problem of estimating the error 
structure of global soil moisture data sets, Geophys. Res. Lett., 35, L24403, doi:10.1029/2008GL035599, 2008b.

Ticehurst, C. J, Bartsch, A., Doubkova, M., and Van Dijk, A. I. J. M.: Comparison of ENVISAT ASAR GM, AMSR-E Passive Microwave, and MODIS Optical Remote Sensing for Flood Monitoring in Australia, Earth Observation and Water Cycle Science, ESA SP-674, Frascati, Italy, 2009.

van Dijk, A. I. J. M. and Renzullo, L. J.: Water resource monitoring systems and the role of satellite observations, Hydrol. Earth Syst. Sci., 15, 39-55, doi:10.5194/hess-15-39-2011, 2011.
Wagner, W. W., Naeimi, V., Scipal, K., De Jeu, R. A. M., and Martinez Fernandez, J.: Soil Moisture from Operational Meteorological Satellites, Hydrogeol. J., 15, 121-131, doi:10.1007/s10040006-0104-6, 2007.

Walker, J. P. and Houser, P. R.: A methodology for initializing soil moisture in a global climate Model: Assimilation of nearsurface soil moisture observations, J. Geophys. Res., 106, 761774, 2001.

Zeng, X., Shaikh, M., Dai, Y., Dickinson, R. E., and Myneni, R.: Coupling of the Common Land Model to the NCAR Community Land Model, J. Climate, 15, 1832-1854, 2002. 